\title{
Mammal diversity among vertical strata and the evaluation of a survey technique in a central Amazonian forest
}

\author{
Alexander Roldán Arévalo-Sandi ${ }^{1,2,5}$; André Luis Sousa Gonçalves ${ }^{1,2,6}$; Kota Onizawa ${ }^{3,7}$; \\ Tsuneaki Yabe ${ }^{4,8}$ \& Wilson Roberto Spironello ${ }^{1,2,9}$
}

\footnotetext{
1 Instituto Nacional de Pesquisas da Amazônia (INPA). Manaus, AM, Brasil.

${ }^{2}$ Grupo de Pesquisa de Mamíferos Amazônicos (GPMA). Manaus, AM, Brasil.

${ }^{3}$ Kyoto University, Wildlife Research Center (WRC). Kyoto, Kansai, Japan.

${ }^{4}$ Hokkaido Research Center, Forestry and Forest Research Institute. Sapporo, Hokkaidō, Japan.

${ }^{5}$ ORCID: http://orcid.org/0000-0003-4284-0246. E-mail: alexander.arevalo85@gmail.com (corresponding author)

${ }^{6}$ ORCID: http://orcid.org/0000-0002-3635-5861. E-mail: sousa.alg@gmail.com

${ }^{7}$ ORCID: http://orcid.org/0000-0003-0461-9321. E-mail: kota.onizawa@gmail.com

${ }^{8}$ ORCID: http://orcid.org/0000-0002-5164-0759. E-mail: tsuneaki.yabe@gmail.com

${ }^{9}$ ORCID: http://orcid.org/0000-0002-3971-3417. E-mail: wrspironello@gmail.com
}

\begin{abstract}
Mammal groups have a vast variety of habitats, which include aquatic, aerial, arboreal, and terrestrial. For terrestrial habitats, camera traps are used as a common technique to record mammals and other vertebrates and have been recently utilized to observe arboreal animals as well. Here, we compare the difference in mammal diversity between floor and canopy strata and evaluate the use of camera trapping in a lowland forest in central Amazon. We installed nine paired camera traps, one in the canopy stratum and other in the floor stratum, in the Alto Cuieiras Biological Reserve (Brazilian Amazon). With a sampling effort of 720 camera-days, we recorded 30 mammal species: nine in canopy strata, 14 in floor strata, and seven in scansorial strata (sharing both strata). On the forest floor, the species with the greatest abundance was Myoprocta acouchy; in the canopy, Isothrix paguros had the greatest abundance; and among the scansorial species, Proechymis sp. was the most abundant. Our results show the differences in mammal diversity between floor and canopy strata; canopy strata contained more small and frugivorous mammals. Although we obtained a relatively low sampling effort with the camera-trap method compared with other studies utilizing different techniques, our results were especially similar to those of previous studies that worked with canopy and floor strata. Thus, camera trap can be very effective for recording short periods of time, and this method is less physically exhaustive and expensive for researchers to study vertical strata.
\end{abstract}

Keywords. Mammals assemblage; Lowland forest; Canopy and floor strata; Monitoring.

\section{INTRODUCTION}

Mammals are one of the most charismatic groups and have a broad variety of habitats, such as aquatic, aerial, terrestrial and arboreal (Ceballos \& Ehrlich, 2002; Wright et al., 2007). Due to the diversity of species, mammals play important roles in ecosystem functioning, and information on their species diversity can elucidate broad ecological processes, such as seed dispersal (de Almeida et al., 2018; Escribano-Avila et al., 2014), seed predation (Mendoza \& Dirzo, 2007), the beetle-mammal network (Raine et al., 2018), and population control of other species by carnivores (Ford \& Goheen, 2015).

The Brazilian Amazon is home to 409 mammal species with 248 species being exclusive for this biome; these species are mostly arboreal (55.7\% excluding aerials) and occupy all the vertical strata (Paglia et al., 2012; Quintela et al., 2020). Regarding vertical strata, $40 \%$ to $70 \%$ of nonvolant mammalian biomass is represented in the canopy stratum (Eisenberg \& Thorington, 1973). Despite the existence of different survey field techniques to monitor mammals in this habitat (e.g., Palmeirim et al., 2019), the canopy stratum is one of the least known environments in the world, termed as the "last biotic frontier" (Bouget et al., 2011; Erwin, 1988; Whitworth et al., 2019a).

Among possible survey techniques, the most commonly used are line transects, live trapping, and camera trapping. The line transect technique (hereafter LnTT) is broadly used to survey midsize to large-bodied mammals, especially those 
with terrestrial and diurnal behaviors (Munari et al., 2011; Peres \& Cunha, 2011; Pontes, 2004). The live-trapping technique (LvTT), which includes Sherman, Tomahawk, and pitfall traps, is especially used for nonvolant small mammals (<1 kg) (Ardente et al., 2017; Malcolm, 1991), which can be located in the canopy stratum (José et al., 2019). Finally, the camera-trapping technique (CTT) is one of the newest to be implemented to mammal surveys, and its use has drastically increased in recent years (Burton et al., 2015; Wearn \& Glover-Kapfer, 2017). This technique can be used to reach a vast variety of difficult habitats, such as canopy habitats, and record elusive and rare species in the wild with more success than the previously described techniques (Bowler et al., 2017; Wearn \& Glover-Kapfer, 2017). While cost-benefit studies show that CTT should be, despite the high initial costs (Silveira et al., 2003), the most appropriate technique for mammal surveys in all environmental conditions (Palmeirim et al., 2019). Nevertheless, most surveys utilizing CTT have focused on the floor stratum (Rowcliffe, 2017; Network, 2011; Tobler et al., 2008), and few recent surveys in the eastern Amazon have focused on the canopy stratum (Gregory et al., 2014; Whitworth et al., 2019b). In this study, we compare the differences in mammal diversity between floor and canopy strata and evaluate the use of CTT compared with other techniques between the vertical strata in a lowland central Amazonian forest. We hypothesize that the canopy strata will have a higher abun- dance of small and frugivorous mammals than those of the floor and CTT will be more efficient than other techniques recording a large number of species in a short period of time.

\section{MATERIAL AND METHODS}

\section{Study Site}

Our study area was in the Cuieiras Biological Reserve located approximately $60 \mathrm{~km}$ northwest of Manaus $\left(02^{\circ} 37^{\prime}\right.$ to $02^{\circ} 38^{\prime} \mathrm{S}, 60^{\circ} 09^{\prime}$ to $60^{\circ} 11^{\prime} \mathrm{W}$ ) (Fig. 1$)$. It has an area of approximately 38,000 ha and is delimited by the BR-174 highway and the Cuieiras River basin (Higuchi, 1981).

The area contains lowland forest habitats with a relatively open understory and dense uniform canopy, with a height range of 30-39 $\mathrm{m}$ and the emergent layer reaching up to $55 \mathrm{~m}$ in height. The soils in these habitats are nutrient-poor sandy and clayey oxisols. The topography is undulating with an average elevation varying between 40 and $160 \mathrm{~m}$ above sea level (m.a.s.l.) (Prance et al., 1990). These variations have a great influence on the forest structure; the forests have visibly different vegetation formations associated with hilltops and slopes of varying inclination. In addition, flooded bottomland swamps may occasionally occur in areas where plateaus are dissected by streams (Oliveira et al., 2008). The av-

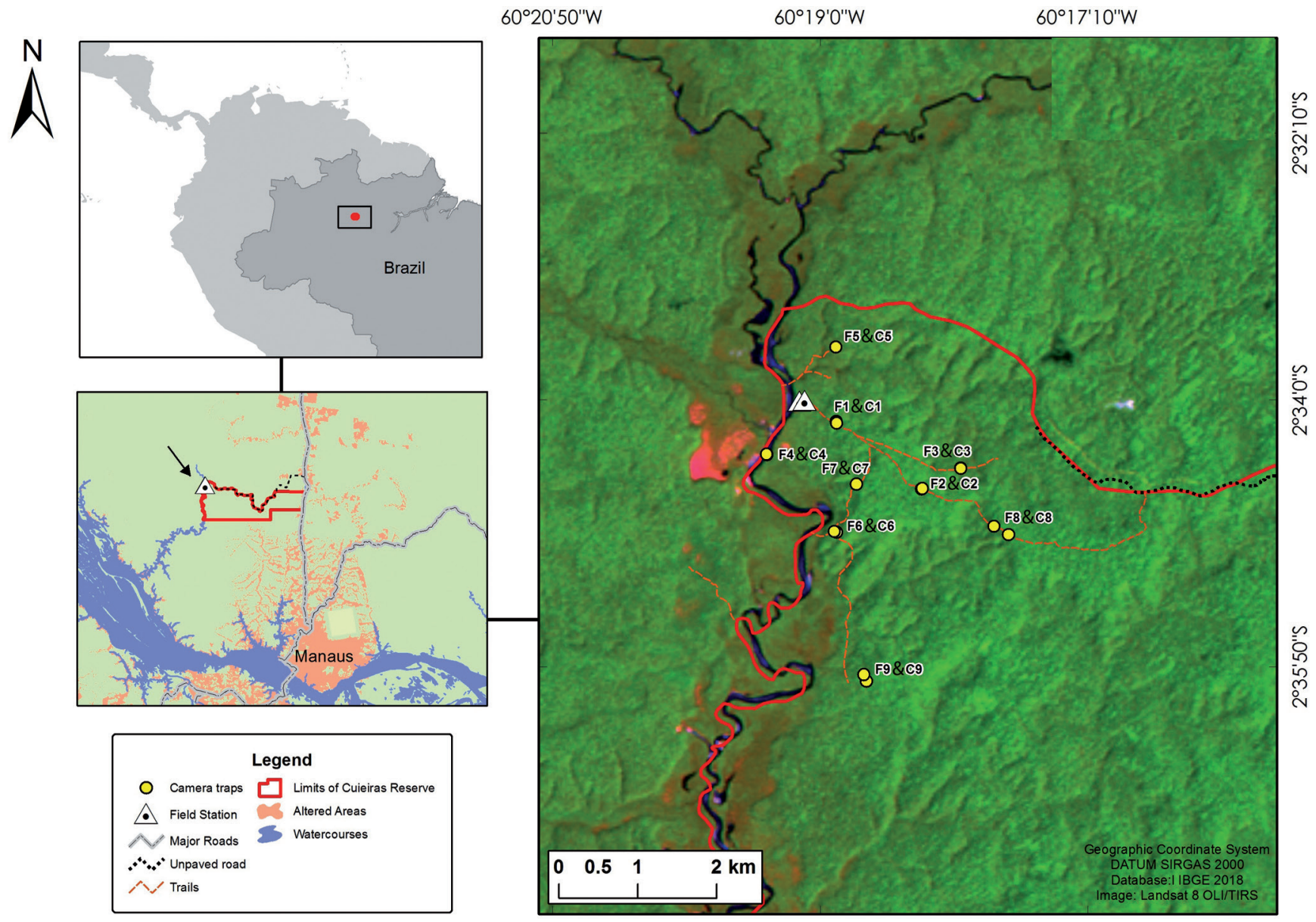

Figure 1. Locations of the nine paired camera traps located in the Cuieiras Biological Reserve, Brazil. F represents the floor stratum and C represents the canopy stratum. 
erage temperature is $26^{\circ} \mathrm{C}$, and the seasons are well defined; most rain fall occurs from December to May (211-300 mm monthly average), and a marked dry season occurs from June to November (42-162 mm monthly average) (Ribeiro \& Adis, 1984).

\section{Data collection and analysis}

We carried out a 40-day camera trap survey from March to April 2018 during the peak of the rainy season. The camera traps were paired; one camera trap focused on the floor stratum and another was placed in the canopy stratum with a total of 22 points (eleven in each stratum) (Fig. 1). The distance among them was between 0.6 and $2 \mathrm{~km}$, covering 600 ha. We used Reconyx UltraFire XR6 (Holmen, WI, USA) passive infrared cameras, which were sealed with silicon for protection from the rain. The cameras recorded continuously 24 hours a day. All cameras were unbaited and programed to record three pictures followed by one video of 15 seconds without intervals between them; we consider this series as one record. For the floor stratum, we installed cameras 20-30 cm above the floor, in areas with signs of mammal presence (e.g., footprints, tracks, feces, and other signs). In these floor areas, we cleared $5 \times 5 \mathrm{~m}$ area in front of each camera of foliage and herbs to prevent falsely triggering cameras and to ensure clear recording and easy identification of observed animals. For the canopy stratum, we installed cameras at a height of $15-20 \mathrm{~m}$ in trees with potential animal footbridges. The points were not necessarily in the same trees where forest floor recordings took place. Four cameras were excluded from the analysis due to malfunctions (two in the canopy stratum and two in the floor stratum).

We processed the camera trap records using the freely available software Timelapse2 (Greenberg \& Godin, 2015). The records were considered independent if taken at least $30 \mathrm{~min}$ apart; when the same species were recorded the same day on the same camera, we used these records as a proxy for abundance (Rovero \& Zimmermann, 2016).

To compare the rate at which new species accumulated in each stratum, we generated sample-based rarefaction/extrapolation curves for species richness and compared them using 95\% confidence intervals drawn from 1,000 randomizations. These rates were also estimated using the first-order jackknife estimator. We considered the richness between strata distinct when the confidence intervals did not overlap curves (Magurran, 2004). We also assessed whether the sampling effort was sufficient enough to record mammal species using these curves. Richness analyses were carried using the iNEXT package (Hsieh et al., 2013). To test the similarity between assemblages, we reduced the matrix dimensionality of midsize to large-bodied mammal species recorded on the floor and canopy strata using a non-metric multidimensional scaling (NMDS) based on the Bray-Curtis similarity index using the "vegan" package (Oksanen et al., 2019). We standardized the camera trap station weights by divid-

Table 1. Sampling effort compared with other techniques in different vertical strata in the Amazon.

\begin{tabular}{|c|c|c|c|c|c|c|c|c|c|c|}
\hline \multirow{3}{*}{ Reference } & \multirow{3}{*}{ Site $^{\mathrm{a}}$} & \multirow{3}{*}{$\begin{array}{c}\text { Nonvolant mammal } \\
\text { group }\end{array}$} & \multirow{2}{*}{\multicolumn{2}{|c|}{$\begin{array}{c}\text { Number of species } \\
\text { by stratum }\end{array}$}} & \multicolumn{6}{|c|}{ Sampling effort by stratumc } \\
\hline & & & & & \multicolumn{3}{|c|}{ Forest floor } & \multicolumn{3}{|c|}{ Canopy } \\
\hline & & & $\begin{array}{c}\text { Forest } \\
\text { floor }\end{array}$ & Canopy & LnTT & LvTT & CTT & LnTT & LvTT & CTT \\
\hline Peres (1997) & Jurua river, western Amazon & Primates & - & 19 & - & - & - & 1564 & - & - \\
\hline Michalski \& Peres (2007) ${ }^{d}$ & Alta Floresta, southern Amazon & Midsize to large & 9 & 30 & 1824 & - & 3086 & - & - & - \\
\hline Tobler et al. $(2008)^{\mathrm{e}}$ & Los Amigos, southwestern Amazon & Midsize to large terrestrial & 35 & 3 & - & - & 3780 & - & - & - \\
\hline Munari et al. $(2011)^{f}$ & Uacari Sustainable Development Reserve, western Amazon & Midsize to large terrestrial & 20 & - & 343 & - & 932 & - & - & - \\
\hline Gregory et al. (2014) ${ }^{9}$ & Pagoreni, lower Urubamba river, southwestern Amazon & Small to large & 18 & 6 & - & - & 1950 & - & - & 3608 \\
\hline Abrahams et al. (2017) & Médio Juruá and Uatumã regions, central-western Amazon & Small to large & 23 & 6 & - & - & $11490^{\mathrm{h}}$ & - & - & - \\
\hline Ardente et al. (2017) & Carajás National Forest, southeastern Amazon & Small & 19 & 13 & - & 28080 & - & - & 34560 & - \\
\hline Blake et al. (2017) & Tiputini Biodiversity Station, northwestern Amazon & Small to large & 24 & 7 & - & - & 5540 & - & - & - \\
\hline Bowler et al. (2017) & Maijuna-Kichwa Regional Conservation Area, nortestern Amazon & Midsize to large arboreal & 4 & 16 & - & - & - & 2014 & - & 3147 \\
\hline Mendes-Oliveira et al. (2017) & ') Agropalma private landholding, eastern Amazon & Small to large & 28 & 9 & 627 & - & 6720 & - & - & - \\
\hline Palmeirim et al. (2019) & Archipelagic landscape of the Balbina Hydroelectric Reservoir, central Amazon & Small & 12 & 13 & - & $19584^{\circ}$ & 6600 & - & - & - \\
\hline Whitworth et al. $(2019 b)^{k}$ & The Manu Biosphere Reserve, southwestern Amazon & Midsize to large & 27 & 21 & - & - & 11253 & - & - & 20364 \\
\hline Present study & Alto Cuieiras Biological Reserve, central Amazon & Small to large & 22 & 14 & 一 & 一 & 360 & - & 一 & 360 \\
\hline
\end{tabular}

a In Amazon biome only.

b According locomotor classification from Paglia et al. (2012). Scansorial is counted for floor and canopy stratum.

Sampling effort: as census effort (km for LnTT, trap-days for LvTT, and camera-days for (TT).

d In this study, line transect census and armadillo surveys were utilized. For practicality, we consider both techniques as line transects only.

e Excluding arboreal, aquatic, and small mammals.

Including species of uncertain identification.

g Authors recorded 16 species in the floor stratum and four in the canopy stratum. To calculate the floor stratum sampling effort, we multiplied the points where the camera traps were installed (13) by the survey days in that stratum (150).

h Calculation of the camera trap station (383) multiplied by the survey days (30). Authors used interviews to complement their records also.

I In this study, pitfall trapping and live trapping were utilized. For practicality, we consider both techniques as live trapping only. Authors placed live traps in three strata: ground, understory, and canopy. For practicality, we calculated the sampling effort for understory and canopy as canopy stratum only. Authors used baited traps.

In this study, pitfall trapping and live trapping were utilized. For practicality, we consider both techniques as live trapping only. In the case of live trapping, authors used baited traps.

k Authors recorded 26 species in the forest stratum and 24 in the canopy stratum; two of these species were escansorial. 
Table 2. Checklist of mammals recorded in vertical strata from Cuieiras Biological Reserve.

\begin{tabular}{|c|c|c|c|c|c|c|c|c|}
\hline \multirow{2}{*}{ Class/Order/Scientific name* } & \multirow{2}{*}{ Common name } & \multicolumn{2}{|c|}{ Records by strata } & \multirow{2}{*}{ Locomotor ${ }^{\mathrm{a} * *}$} & \multirow{2}{*}{$\operatorname{Diet}^{b * *}$} & \multirow{2}{*}{ IUCN } & \multirow{2}{*}{$\begin{array}{l}\text { Mean body } \\
\text { mass }(\mathbf{k g})^{* *}\end{array}$} & \multirow{2}{*}{$\begin{array}{c}\text { Calculated } \\
\text { biomass }(\mathrm{Kg})^{c}\end{array}$} \\
\hline & & Forest floor & Canopy & & & & & \\
\hline \multicolumn{9}{|l|}{ MAMMALIA } \\
\hline \multicolumn{9}{|l|}{ Perissodactyla } \\
\hline Tapirus terrestris (Linnaeus, 1758) & South American Tapir & 6 & - & Te & $\mathrm{Hb} / \mathrm{Fr}$ & VU & 260 & 1560 \\
\hline \multicolumn{9}{|l|}{ Artiodactyla } \\
\hline Mazama americana (Erxleben, 1777) & Red Brocket & 1 & - & Te & $\mathrm{Fr} / \mathrm{Hb}$ & LC & 36 & 36 \\
\hline Mazama nemorivaga (F. Cuvier, 1817) & Brown Brocket Deer & 7 & - & Te & $\mathrm{Fr} / \mathrm{Hb}$ & LC & 20 & 140 \\
\hline Pecari tajacu (Linnaeus, 1758) & Collared Peccary & 9 & - & Te & $\mathrm{Fr} / \mathrm{Hb}$ & LC & 26 & 234 \\
\hline \multicolumn{9}{|l|}{ Pilosa } \\
\hline Tamandua tetradactyla (Linnaeus, 1758) & Southern Tamandua & 1 & 1 & Sc & Myr & LC & 5,2 & 10,4 \\
\hline \multicolumn{9}{|l|}{ Cingulata } \\
\hline Dasypus spp. (Linnaeus, 1758) & Seven or nine banded Armadillo & 11 & - & Te & $\ln / 0 \mathrm{n}$ & LC & 6,55 & 72,05 \\
\hline \multicolumn{9}{|l|}{ Primates } \\
\hline Sapajus apella (Linnaeus, 1758) & Brown Tufted Capuchin & - & 8 & $\operatorname{Ar}$ & $\mathrm{Fr} / 0 \mathrm{n}$ & LC & 3,05 & 24,4 \\
\hline Saguinus midas (Linnaeus, 1758) & Golden-handed Tamarin & - & 4 & $\mathrm{Ar}$ & $\mathrm{Fr} / \mathrm{ln}$ & $\mathrm{LC}$ & 0,505 & 2,02 \\
\hline \multicolumn{9}{|l|}{ Rodentia } \\
\hline Cuniculus paca (Linnaeus, 1766) & Spotted Paca & 15 & - & Te & $\mathrm{Fr} / \mathrm{Hb}$ & $\mathrm{LC}$ & 9,3 & 139,5 \\
\hline Dasyprocta leporina (Linnaeus, 1758) & Red-rumped Agouti & 132 & - & Te & $\mathrm{Fr} / \mathrm{Gr}$ & LC & 5,75 & 759 \\
\hline Myoprocta acouchy (Erxleben, 1777) & Red Acouchi & 171 & - & Te & $\mathrm{Fr} / \mathrm{Gr}$ & LC & 1,2 & 205,2 \\
\hline Coendou melanurus (Wagner, 1842) & Black-tailed Hairy Dwarf Porcupine & - & 10 & $\operatorname{Ar}$ & $\mathrm{Fr} / \mathrm{Fo}$ & LC & 1,95 & 19,5 \\
\hline Isothrix pagurus (Wagner, 1845) & Plain brush-tailed Rat & - & 26 & $\operatorname{Ar}$ & $\mathrm{Fr} / \mathrm{Fo}_{0}$ & LC & 0,4 & 10,4 \\
\hline Makalata didelphoides (Desmarest, 1817) & Red-nosed Armored Tree-rat & 1 & 3 & $\operatorname{Ar}$ & Fo & LC & 0,32 & 1,28 \\
\hline Proechymis spp. Allen, 1899 & Spiny-rat & 26 & 2 & Te & $\mathrm{Fr} / \mathrm{Gr}$ & LC & 0,36 & 10,08 \\
\hline Guerlinguetus aestuans (Linnaeus, 1766) & Guianan Squirrel & 4 & 1 & Sc & $\mathrm{Fr} / 0 \mathrm{n}$ & LC & 0,19 & 0,95 \\
\hline Oecomys spp. Thomas, 1906 & Arboreal Rice Rat & 1 & 5 & $\operatorname{Ar}$ & $\mathrm{Fr} / \mathrm{Se}$ & $\mathrm{LC}$ & 0,04 & 1,44 \\
\hline \multicolumn{9}{|l|}{ Didelphimorphia } \\
\hline Didelphis marsupialis (Linnaeus, 1758) & Common Opossum & 12 & 6 & Sc & $\mathrm{Fr} / 0 \mathrm{n}$ & LC & 1,35 & 24,3 \\
\hline Philander opossum (Linnaeus, 1758) & Gray Four-Eyed Opossum & 9 & - & Sc & $\ln / 0 \mathrm{n}$ & LC & 0,49 & 4,41 \\
\hline Metachirus spp. & Brown Four-eyed Opossum & 17 & - & Te & $\ln / 0 \mathrm{n}$ & $\mathrm{LC}$ & 0,39 & 6,63 \\
\hline Caluromys philander (Linnaeus, 1758) & Bare-tailed Woolly Opossum & - & 13 & $\operatorname{Ar}$ & $\mathrm{Fr} / 0 \mathrm{n}$ & LC & 0,265 & 3,445 \\
\hline Glironia venusta (Thomas, 1912) & Bushy-tailed opossum & - & 4 & $\operatorname{Ar}$ & $\ln / 0 \mathrm{n}$ & LC & 0,15 & 0,6 \\
\hline Marmosa murina (Linnaeus, 1758) & Linnaeus's Mouse Opossum & - & 3 & Sc & $\ln / 0 \mathrm{n}$ & LC & 0,05 & 0,15 \\
\hline Marmosa (Micoureus) demerarae (Thomas, 1905) & Woolly Mouse Opossum & - & 9 & $\operatorname{Ar}$ & $\ln / 0 n$ & LC & 0,12 & 1,08 \\
\hline \multicolumn{9}{|l|}{ Carnivora } \\
\hline Nasua nasua (Linnaeus, 1766) & South American Coati & 1 & - & Te & $\mathrm{Fr} / 0 \mathrm{n}$ & LC & 5,1 & 5,1 \\
\hline Potos flavus (Schreber, 1774) & Kinkajou & - & 1 & SC & $\mathrm{Fr} / \mathrm{On}$ & LC & 2,6 & 2,6 \\
\hline Eira barbara (Linnaeus, 1758) & Tayra & 1 & 1 & Sc & $\mathrm{Fr} / 0 \mathrm{n}$ & LC & 7,05 & 14,1 \\
\hline Puma concolor (Linnaeus, 1771) & Cougar & 1 & - & Te & $\mathrm{Ca}$ & LC & 46 & 46 \\
\hline Leopardus pardalis (Linnaeus, 1758) & Ocelot & 5 & - & Te & $\mathrm{Ca}$ & $\mathrm{LC}$ & 9,55 & 47,75 \\
\hline Herpailurus yagouaroundi (É. Geoffroy Saint-Hilaire, 1803) & Jaguarundi & 2 & - & Te & $\mathrm{Ca}$ & $\mathrm{LC}$ & 4,55 & 9,1 \\
\hline
\end{tabular}

* From Quintela et al (2020).

** From Paglia et al. (2012).

a Ar: Arboreal; Sc: Scansorial; Te: Terrestrial.

b Hb: Herbivore grazer; Fr: Frugivore; Myr: Myrmecophage; In: Insectivore; On: Omnivore; Gr: Granivore; Fo: Folivore; Se: Seed predator; Ca: Carnivore.

c Assuming every record as an individual, we multiplied records by the strata and mean body mass (kg).

ing the number of records of each species by the total number of records of the camera trap station (decostand function, MARGIN = 1). Subsequently, we compared the assemblages of both strata using a multi-response permutation procedure (mrpp function, "vegan" package) based on the Bray-Curtis index with 9,999 permutations (Oksanen et al., 2019). We used the multiple-response permutation procedure (MRPP) test statistic with an $\mathrm{R}$ value to determine the degree of similarity between treatments (i.e., strata) (Legendre \& Legendre, 1998). All analyses were performed using the $\mathrm{R}$ language and environment for statistical computing (R Core Team, 2018).

\section{RESULTS AND DISCUSSION}

We obtained a sampling effort of 720 camera-days (360 for each stratum; Table 1). Through this, we obtained 433 independent records for the floor stratum and 97 for the canopy stratum. These records included 30 mammal species representing eight orders: Perissodactyla, Artiodactyla, Pilosa, Cingulata, Primates, Rodentia (with the highest record, 397), Didelphimorphia, and Carnivora (Table 2). As shown in Table 2, we recorded nine nonvolant mammals' species exclusive to the canopy stratum, 14 exclusive to the floor stratum, and seven scansorial 

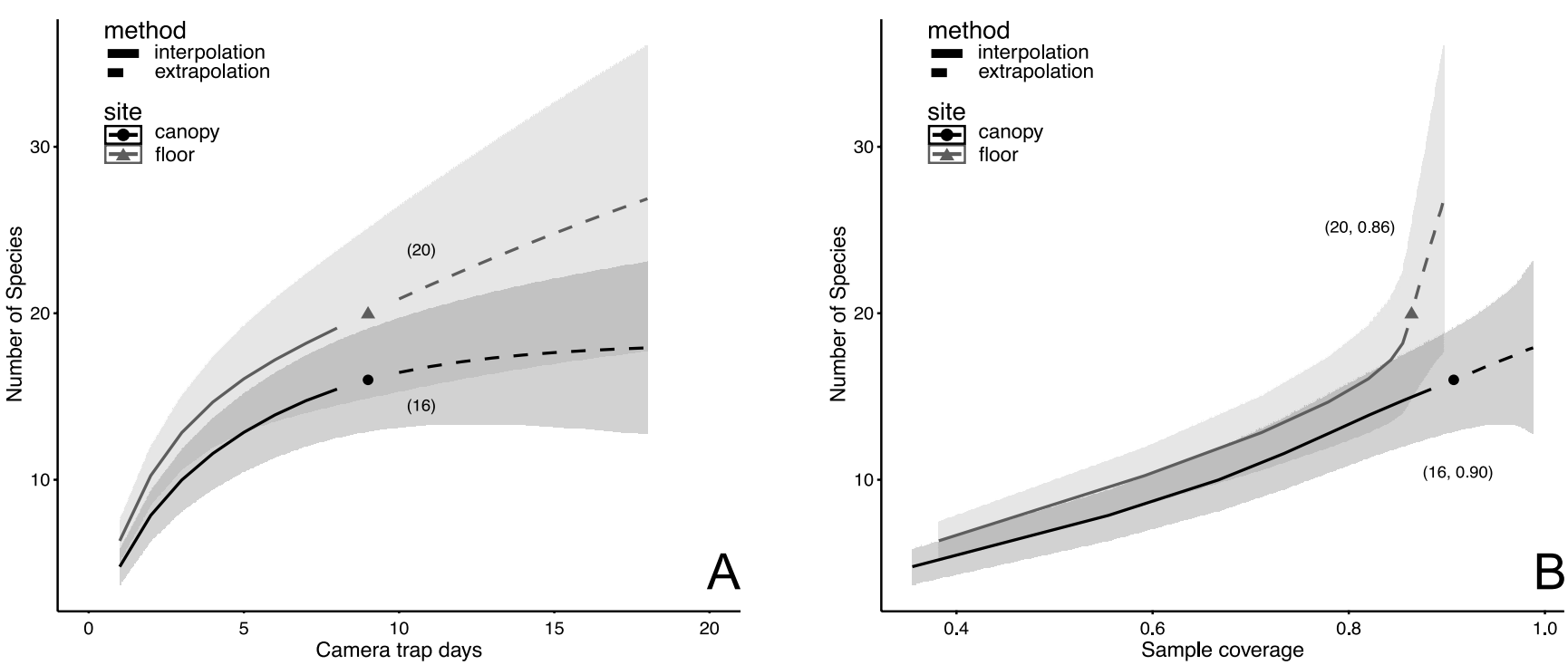

Figure 2. Species accumulation curve for (A) sampling effort (camera trap days) and (B) completeness of vertical strata.
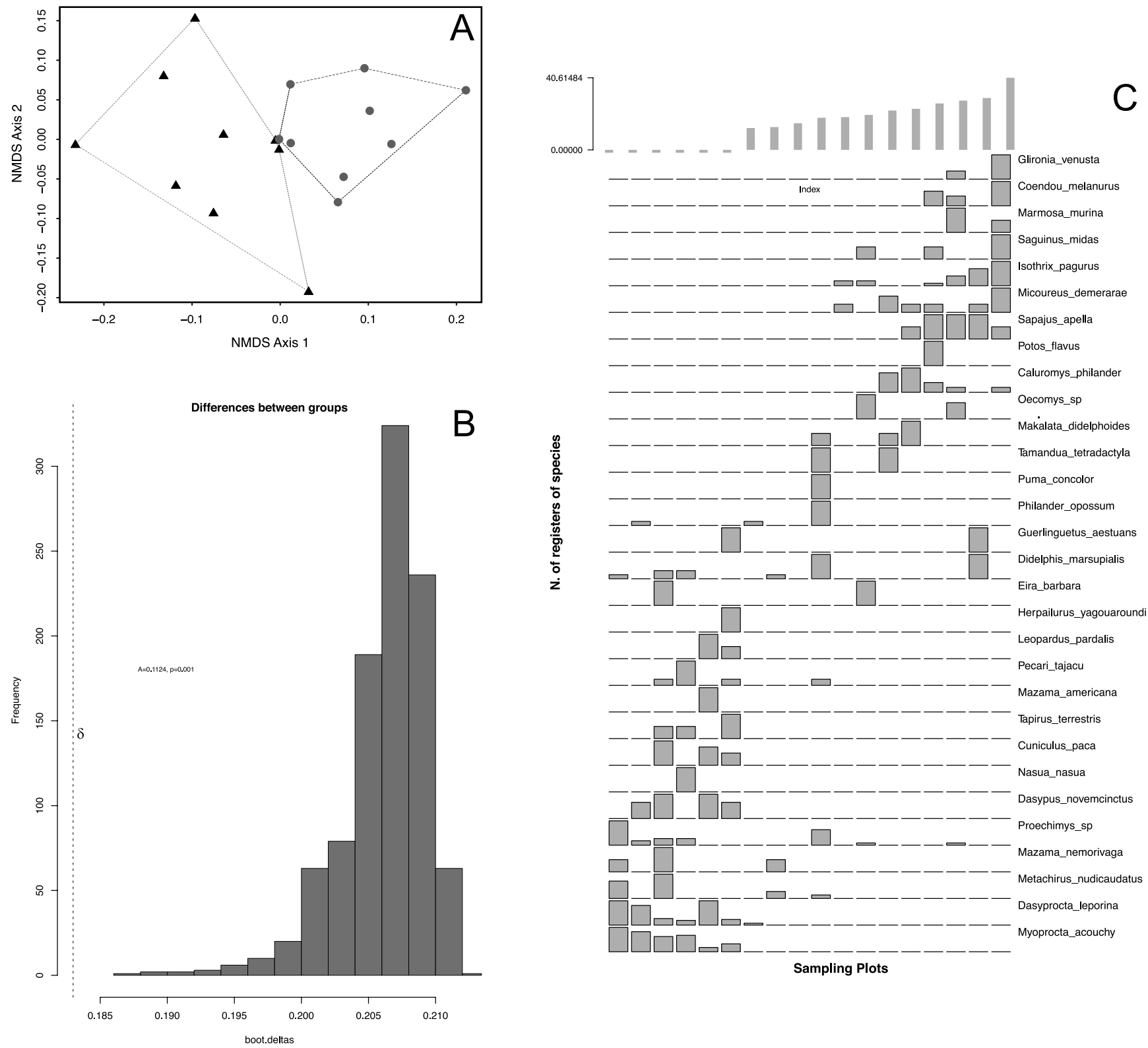

Figure 3. Midsized to large mammal assemblages in vertical strata. (A) Similarity in mammal species composition (black triangles represent the floor assemblage and gray circles represent the canopy assemblage). (B) Differences between groups according to MRPP analyses. (C) Distribution of mammals across sample sites. 
species (or shared both strata). Of all species recorded in the canopy strata (including scansorial, i.e. 16 species), $62.5 \%$ (10 species) were small-bodied mammals.Among small to large species observed in this stratum, $68.75 \%$ (11 species) are considered frugivorous according to the classification by Paglia et al. (2012). Among records (a proxy for abundance for (TT), with a total of 77 records for all frugivorous species in canopy strata, it was recorded $66.23 \%$ (51 records) of small-bodied mammals. For the canopy stratum, the Plain brush-tailed rat Isothrix pagurus (Wagner, 1845) was the most abundant species; for the forest floor stratum, the acouchi Myoprocta acouchy (Erxleben, 1777) was the most abundant species; and among the scansorial species, Proechymis sp. was the most abundant (Table 2).

The species accumulation curves for small to large terrestrial mammal species show more species detected per unit effort on the floor strata ( $20 \pm 3.5 \mathrm{SE}$ ) compared with the canopy strata ( $16 \pm 2.6 \mathrm{SE}$ ) (Fig. 2a). However, the estimated sampling completeness was lower than $86 \%$ for the floor assemblage (Fig. 2b). This finding was reinforced by the accumulation curves that do not show a complete stabilization trend. This outcome indicates that the sampling effort, although good, was not enough to represent all species of mammal fauna in the study site. Therefore, an increase in the sampling effort is expected to reveal some species that were not recorded (Fig. 2).

Species composition by sampling points was hardly grouped between the floor and canopy strata, as shown by the NMDS. The first two axes captured $82 \%$ of the variance in the data (Fig. 3a), which can be better represented by MRPP analyses ( $A=0.112 ; p<0.001$ ) (Fig. 3b), showing species that are exclusive to every stratum with exception of a few species (Fig. 3c).

Although we obtained a relatively low sampling effort with CTT compared with other studies utilizing different techniques (Table 1), we recorded a similar number of mammal species with the other techniques. Our results were especially similar to those of previous studies that worked with canopy and floor strata (Ardente et al., 2017; Gregory et al., 2014; Whitworth et al., 2019b). This finding may indicate a minimum CTT sampling effort for mammal groups in both strata. Furthermore, we believe that to have a larger number of species, it may be necessary to use the other techniques together to complement and increase the records of species that are not easily seen in a short time. Interviews (Michalski \& Peres, 2007; Abrahams et al., 2017) and signs (Norris, 2014; Fragoso et al., 2016) are some methods that can complement the previously mentioned methods to help record the presence of species in a short period of time. Some proof of this finding is the difference between the percentages of accumulated biomass (Table 2) for the strata found in our study: 3,200 kg (98.7\%) for the floor stratum and $42 \mathrm{~kg}(1.7 \%)$ for the canopy stratum. These results differed from the reports of Eisenberg \& Thorington (1973) who found that more than $50 \%$ of mammal biomass was composed of sloths and howler monkeys - species found in the canopy stratum - which were precisely the species that we could not record in our study.

\section{CONCLUSION}

Monitoring mammal diversity can be expensive, and collecting adequate data is often difficult.

We concluded that the floor forest is more diverse (21 species recorded) and was composed of a broad size of animals (small to large) and more trophic guilds variety than the canopy. However, in the canopy, we mostly observed small, frugivorous mammals that can be great contributors for primary seed dispersal.

CTT can be very effective for recording short periods of time, and this method is less physically exhaustive for researchers to study vertical strata.

If we want to record the total diversity of species in the area, including less abundant and rare species, then we will need a greater sampling effort in combination with other survey techniques.

\section{ACKNOWLEDGMENTS}

The authors are grateful to the Museu na Floresta, an agreement of Instituto Nacional de Pesquisas da Amazônia (INPA), Japan Science and Technology Agency (JST), Japan International Cooperation Agency (JICA) and Kyoto University, for financial and logistical support for this study. The authors would like to thank Enago (www.enago.jp) for the English language review. ARAS is grateful to Coordenação de Aperfeiçoamento de Pessoal de Nível Superior (CAPES) and Conselho Nacional de Desenvolvimento Científico e Tecnológico (CNPq) for granting a PhD program scholarship. ALSG is grateful to Fundação de Amparo à Pesquisa do Estado do Amazonas (FAPEAM) for granting a PhD program scholarship. This is publication number 52 from the Amazonian Mammals Research Group.

\section{AUTHORS' CONTRIBUTIONS}

All authors conceived of the presented idea and theory of the manuscript. A.R.A.S. developed the written and led the team. A.L.S.G., K.O., T.Y., and W.R.S. did the fieldwork data collection. A.L.S.G. performed the computations, analyses, and created the map. All authors verified the analytical methods. All authors discussed the results and contributed to the final manuscript. All authors reviewed and approved the final version of the paper.

\section{REFERENCES}

Abrahams, M.I.; Peres, C.A. \& Costa, H.C.M. 2017. Measuring local depletion of terrestrial game vertebrates by central-place hunters in rural Amazonia. PLOS ONE, 12: e0186653.

de Almeida, A.; Morris, R.J.; Lewis, 0.T. \& Mikich, S.B. 2018. Complementary roles of two resilient neotropical mammalian seed dispersers. Acta Oecologica, 88: 9-18.

Ardente, N.C.; Ferreguetti, A.C.; Gettinger, D.; Leal, P.; Martins-Hatano, F. \& Bergallo, H.G. 2017. Differencial efficiency of two sampling methods in 
capturing non-volant small mammals in an area in eastern Amazonia. Acta Amazonica, 47: 123-132.

Blake, J.G.; Mosquera, D.; Loiselle, B.A.; Swing, K. \& Romo, D. 2017. Longterm variation in abundance of terrestrial mammals and birds in eastern Ecuador as measured by photographic rates and occupancy estimates. Journal of Mammalogy, 98: 1168-1178.

Bouget, C.; Brin, A. \& Brustel, H. 2011. Exploring the "last biotic frontier": are temperate forest canopies special for saproxylic beetles? Forest Ecology and Management, 261(2): 211-220.

Bowler, M.T.; Tobler, M.W.; Endress, B.A.; Gilmore, M.P. \& Anderson, M.J. 2017. Estimating mammalian species richness and occupancy in tropical forest canopies with arboreal camera traps. Remote Sensing in Ecology and Conservation, 3(3): 146-157.

Burton, A.C.; Neilson, E.; Moreira, D.; Ladle, A.; Steenweg, R.; Fisher, J.T.; Bayne, E. \& Boutin, S. 2015. Wildlife camera trapping: a review and recommendations for linking surveys to ecological processes. Journal of Applied Ecology, 52(3): 675-685.

Ceballos, G. \& Ehrlich, P.R. 2002. Mammal population losses and the extinction crisis. Science, 296(5569): 904-907.

Eisenberg, J.F. \& Thorington-Jr., R.W. 1973. A preliminary analysis of a neotropical mammal fauna. Biotropica, 5(3): 150-161.

Erwin, T.L. 1988. The tropical forest canopy. In:Wilson, E.O. \& Peter, M.P. (Eds.). Biodiversity. Washington, D.C., National Academy Press. p. 123-129.

Escribano-Avila, G.; Calviño-Cancela, M.; Pías, B.; Virgós, E.; Valladares, F. \& Escudero, A. 2014. Diverse guilds provide complementary dispersal services in a woodland expansion process after land abandonment. Journal of Applied Ecology, 51(6): 1701-1711.

Ford, A.T.\& Goheen, J.R. 2015. Trophic cascades by large carnivores: a case for strong inference and mechanism. Trends in Ecology \& Evolution, 30(12): 725-735.

Fragoso, J.M.V.; Levi, T.; Oliveira, L.F.B.; Luzar, J.B.; Overman, H.; Read, J.M. \& Silvius, K.M. 2016. Line transect surveys underdetect terrestrial mammals: Implications for the sustainability of subsistence hunting. Plos One, 11: e0152659.

Greenberg, S. \& Godin, T. 2015. A tool supporting the extraction of angling effort data from remote camera images. Fisheries, 40(6): 276-287.

Gregory, T.; Carrasco Rueda, F.; Deichmann, J.; Kolowski, J. \& Alonso, A. 2014. Arboreal camera trapping: taking a proven method to new heights. Methods in Ecology and Evolution, 5: 443-451.

Higuchi, N. 1981. A silvicultura no INPA. Acta Amazonica, 11: 99-107.

Hsieh, T.C.; Ma, K.H. \& Chao A. 2013. iNEXT online: interpolation and extrapolation. Version 2.0.20. Available: http://chao.stat.nthu.edu.tw/ wordpress/software download/inext-online. Access: 19/02/2020.

José, H.; Macedo, I. \& Loss, M.C. 2019. A New and Simple Method to Capture Small Arboreal Mammals: The Suspended Pitfall. Revista Brasileira de Zoociências, 20: 1-14.

Legendre, P. \& Legendre, L. 1998. Numerical ecology: developments in environmental modelling. 2. ed. Amsterdam, English ed. Elsevier. 853p.

Magurran, A.E. 2004. Measuring biological diversity. Wiley-Blackwell. 266p.

Malcolm, J.R. 1991. Comparative abundances of Neotropical small mammals by trap height. Journal of Mammalogy, 72: 188-192.

Mendes-Oliveira, A.C.; Peres, C.A.; Maués, P.C.R.D.A.; Oliveira, G.L.; Mineiro, I.G.; de Maria, S.L.S. \& Lima, R.C. 2017. Oil palm monoculture induces drastic erosion of an Amazonian forest mammal fauna. PLOS ONE, 12: e0187650.

Mendoza, E. \& Dirzo, R. 2007. Seed-size variation determines interspecific differential predation by mammals in a neotropical rain forest. Oikos, 116(11): 1841-1852.

Michalski, F. \& Peres, C.A. 2007. Disturbance-mediated mammal persistence and abundance-area relationships in Amazonian forest fragments. Conservation Biology, 21(6): 1626-1640. DOI
Munari, D.P.; Keller, C. \& Venticinque, E.M. 2011. An evaluation of field techniques for monitoring terrestrial mammal populations in Amazonia. Mammalian Biology, 76(4): 401-408.

Network, T. 2011. Terrestrial vertebrate protocol implementation manual, v. 3.1. In: Tropical Ecology, Assessment and Monitoring Network. Arlington, VA, Center for Applied Biodiversity Science, Conservation International, USA.

Norris, D. 2014. Model thresholds are more important than presence location type: Understanding the distribution of lowland tapir (Tapirus terrestris) in a continuous Atlantic forest of southeast Brazil. Tropical Conservation Science, 7(3): 529-547.

Oksanen, J.; Blanchet, F.G.; Friendly, M.; Kindt, R.; Legendre, P.; McGlinn, D.; Minchin, P.R.; O'Hara, R.B.; Simpson, G.L.; Solymos, P.; Stevens, M.H.H.; Szoecs, E. \& Wagner, H. 2019. Vegan: community ecology package. $R$ package version 2.5-6. Available: http://CRAN.R-project.org/ package $=$ vegan. . Access: 10/01/2020.

Oliveira, M.L.; Baccaro, F.B.; Braga-Neto, R. \& Magnusson, W.E. 2008. Reserva Ducke: a biodiversidade através de uma grade. Manaus, AM, Áttema Design Editorial. 166p.

Paglia, A.P.; da Fonseca, G.A.B.; Rylands, A.B.; Herrmann, G.; Aguiar, L.M.S.; Chiarello, A.G.; Leite, Y.L.R.; Costa, L.P.; Siciliano, S.; Kierulff, M.C.M.; Mendes, S.L.; Tavares, V.C.; Mittermeier, R.A. \& Patton, J.L. 2012. Lista anotada dos mamíferos do Brasil. 2. Ed. Annotated checklist of Brazilian mammals. Occasional Papers in Conservation Biology, 6: 1-82.

Palmeirim, A.F.; Benchimol, M.; Peres, C.A. \& Vieira, M.V. 2019. Moving forward on the sampling efficiency of neotropical small mammals: insights from pitfall and camera trapping over traditional live trapping. Mammal Research, 64(3): 445-454.

Peres, C.A. 1997. Primate community structure at twenty western Amazonian flooded and unflooded forests. Journal of Tropical Ecology, 13: 381-405.

Peres, C.A. \& Cunha, A.A. 2011. Manual para censo e monitoramento de vertebrados de médio e grande porte por transecção linear em florestas tropicais. Brasılia, Wildlife Conservation Society.

Pontes, A.R.M. 2004. Ecology of a community of mammals in a seasonailly dry forest in Roraima, Brazilian Amazon. Mammalian Biology, 69(5): 319-336.

Prance, G.T. 1990. The floristic composition of the forests of central Amazonian Brazil. In: Gentry, A. (Ed.). Four neotropical forests. New Haven, Yale University Press. p. 112-140.

Quintela, F., Da Rosa, C.A. \& Feijó, A. 2020. Updated and annotated checklist of recent mammals from Brazil. Anais da Academia Brasileira de Ciências, 92(Suppl. 2): e20191004.

Raine, E.H.; Mikich, S.B.; Lewis, 0.T.; Riordan, P.; Vaz-de-Mello, F.Z. \& Slade, E.M. 2018. Extinctions of interactions: quantifying a dung beetlemammal network. Ecosphere, 9: e02491.

Ribeiro, M.G.R. \& Adis, J. 1984. Local rainfall variability a potential bias for bioecological studies in the central Amazon. Acta Amazonica, 14: 159-174.

Rovero, F. \& Zimmermann, F. 2016. Camera trapping for wildlife research. Pelagic, Elsevier. 433p.

Rowcliffe, M.J. 2017. Key frontiers in camera trapping research. Remote Sensing in Ecology and Conservation, 3(3): 107-108.

Silveira, L.; Jacomo, A.T.A. \& Diniz-Filho, J.A.F. 2003. Camera trap, line transect census and track surveys: a comparative evaluation. Biological Conservation, 114(3): 351-355.

The R Project for Statistical Computing (R Core Team). 2018. R: A language and environment for statistical computing. Vienna, R Foundation for Statistical Computing. https://www.R-project.org.

Tobler, M.W.; Carrillo-Percastegui, S.E.; Pitman, R.L.; Mares, R. \& Powell, G. 2008. An evaluation of camera traps for inventorying large-and 
medium-sized terrestrial rainforest mammals. Animal Conservation, 11(3): 169-178.

Wearn, 0.R. \& Glover-Kapfer, P. 2017. Camera-trapping for conservation: a guide to best-practices. United Kingdom, WWF-UK, Woking. 181p.

Whitworth, A.; Whittaker, L.; Pillco Huarcaya, R.; Flatt, E.; Morales, M.L.; Connor, D.; Priego, M.G.; Forsth, A. \& Beirne, C. 2019a. Spider monkeys rule the roost: ateline sleeping sites influence rainforest heterogeneity. Animals, 9(12): 1052.
Whitworth, A.; Beirne, C.; Pillco Huarcaya, R.; Whittaker, L.; Serrano Rojas, S.J.; Tobler, M.W. \& MacLeod, R. 2019b. Human disturbance impacts on rainforest mammals are most notable in the canopy, especially for larger-bodied species. Diversity and Distributions, 25(7): 1166-1178.

Wright, S.J.; Stoner, K.E.; Beckman, N.; Corlett, R.T.; Dirzo, R.; Muller-Landau, H.C.; Nuñes-Iturri, G.; Peres, C.A. \& Wang, B.C. 2007. The plight of large animals in tropical forests and the consequences for plant regeneration. Biotropica, 39(3): 289-291. 